\title{
PROFIL KREATIVITAS SISWA SMP DALAM \\ MENYELESAIKAN MASALAH MATEMATIKA DITINJAU BERDASARKAN PERBEDAAN TEMPERAMEN
}

\author{
Oleh: Ririn Febriyanti \\ STKIP PGRI JOMBANG \\ E-mail: ririn febriyanti00@yahoo.com
}

\begin{abstract}
Abstrak:
Pertanyaan dalam penelitian ini adalah (1). Bagaimana profil kreativitas siswa SMP dengan temperamen melankoli dalam menyelesaikan masalah matematika? (2). Bagaimana profil kreativitas siswa SMP dengan temperamen sanguin dalam menyelesaikan masalah matematika? (3). Bagaimana profil kreativitas siswa SMP dengan temperamen phlegmatik dalam menyelesaikan masalah matematika? (4). Bagaimana profil kreativitas siswa SMP dengan temperamen kolerik dalam menyelesaikan masalah matematika?.Penelitian ini termasuk jenis penelitian deskriptif dengan pendekatan kualitatif. Subjek penelitian ini terdiri empat orang siswa kelas VIII SMP "Nasional" Ngoro Mojokerto yang dipilih berdasarkan angket temperamen yang diadaptasi peneliti dari i daftar pertanyaan temperamen yang dibuat oleh Florence Littauer (2011). Data penelitian ini diperoleh dengan cara memberikan tes pemecahan masalah matematika kepada subjek penelitian. Hasil penelitian menunjukan Kreativitas siswa dengan temperamen kolerik dari aspek kefasihannya subjek mampu menggambar 7 jawaban yang berbeda dan bernilai benar. Jawaban yang ia tuliskan bervariasi baik bentuk bangun maupun perhitungannya. Siswa dengan temperamen kolerik dalam aspek fleksibilitas memberikan cara yang berbeda yaitu menggunakan volume bangun ruang, menggunakan kotak mainan, mengadakan percobaan fisika, melihat sudut-sudut yang bersesuaian. Dari aspek orisinal, subjek menjelaskan munculnya ide dari kehidupan sehari-hari.(2). Kreativitas oleh siswa SMP dengan temperamen sanguin dalam aspek kefasihan subjek membagi kue bolu menjadi dua bagian yang sama. Aspek fleksibilitas subjek hanya mampu menemukan satu cara yaitu dengan menggunakan rumus volume bangun ruang. Penyelesaian yang dibuatnya berasal dari pikian siswa itu sendiri. Sedangkan aspek orisinal menjelaskan asal ide diperoleh dari pengalaman sendiri. (3). Kreativitas siswa SMP dengan temperamen phlegmatis pada aspek kefasihan subjek menuliskan sebanyak 5 jawaban,tetapi dalam aspek fleksibiltas hanya bisa menggambar lalu menentukan ukurannya dan rumus volumenya untuk menghitung volumenya. Pada aspek orisinal subjek terinspirasi dari kegiatan yang dilakukan baik dari subjek sendiri ataupun dari orang-orang sekitar, (4). Kreativitas dalam menyelesaikan masalah matematika oleh siswa SMP dengan temperamen melankolik dalam aspek kefasihan subjek hanya mampu menuliskan 2 jawaban. Subjek dalam aspek fleksibilitas hanya bisa menggambar lalu menentukan ukurannya dan rumus volumenya.Pada aspek orisinal, subjek berangan-angan kalau kue tersebut akan dibagi di tengah-tengah panjang kue tersebut.
\end{abstract}

Kata-kata Kunci:profil, kreativitas, masalahmatematika, temperamen 


\section{Pendahuluan}

Sistem pembelajaran di sekolah sudah banyak mengalami perubahan. Salah satunya adalah perubahan sifat pembelajaran yang berorientasi pada guru (teacher oriented) atau biasa disebut teacher centered saat ini sifatnya berubah berorientasi pada siswa (student oriented) atau student centered. Begitu juga halnya dengan pembelajaran matematika yang mempunyai fokus untuk mengembangkan kemampuan berpikir kreatif. Melalui pembelajaran matematika, siswa diharapkan memiliki kemampuan berpikir logis, analitis, sistematis, kritis, dan kreatif, serta mampu bekerja sama (Depdiknas, 2004).

McGregor(2007), mengukur kemampuan berpikir kreatif siswa dapat pula dilakukan denganmendasarkan pada apa yang dikomunikasikan siswa, secara verbal maupuntertulis.Dalam hal ini,aspek-aspek yang diukur adalah kelancaran, keluwesan, dan kebaruan, dan keterincian. Kelancaran berkaitan dengan banyaknya solusi. Keluwesan berkaitan dengan ragam ide. Kebaruan berkaitan dengan keunikan jawaban siswa.Sedangkan aspek keterincian berkaitan keterincian dan keruntutan jawaban. Kemampuan yang dimiliki oleh setiap siswa dalam kemampuan berpikirnya tentunya berbeda-beda. Pada dasarnya setiap orang mempunyai kemampuan berpikir, hanya kadarnya yang berbeda-beda sehingga kecepatan perkembangan kemampuan berpikirnya juga berbeda.Perilaku dan sikap menurut Imanuel Kant juga dipengaruhi oleh temperamen (Siagian, 2003).

Menurut Health (Sutanto, 2003) temperamen adalah perpaduan sifat-sifat pembawaan, yang tanpa sadar mempengaruhi sikap dan tingkah laku. Temperamen merupakan irama hidup dan sifat dasar bawaaan seseorang. Hippocrates, seorang bapak ilmu pengobatan dari Yunani (460-370SM), mengemukakan suatu teori yang mengatakan bahwa pada dasarnya ada 4 (empat) tipe temperamen dasar yang dimiliki oleh manusia berdasarkan keberadaan cairancairan dalam proporsi tertentu. Keempat tipe temperamen itu yaitu tipe sanguin (the sanguine type), tipe kolerik (the choleric type), tipe melankoli (melancholy type), tipe plegmatik (phlegmatic type). Ormrod (2008) menyebutkan bahwa perilaku anak dipengaruhi oleh temperamen (faktor yang diwariskan), dan lingkungan. Hal ini ditunjang dengan 
pendapat Guilford bahwa kemampuan kreatif menentukan apakah individu memiliki kekuatan untuk menampilkan perilaku kreatif. Apakah individu yang memiliki kemampuan bisa atau tidak bisa mengaktualkan hasil kreatif tergantung pada motivasi dan temperamen. Berdasarkan pendapat Anderson dan Ormrod, peneliti menduga bahwa terdapat perbedaan kreativitas yang didasarkan pada temperamen.Peneliti ingin melakukan penelitian tentang profil kreativitas siswa Sekolah Menengah Pertama berdasarkan temperamen pada siswa-siswa SMP.

Tujuan penelitian ini adalah: Untuk mendeskripsikan profil kreativitas siswa SMP dengan temperamen melankoli, sanguin, phlegmatik, kolerik dalam menyelesaikan masalah matematika.Hasil yang diperoleh dari penelitian ini diharapkan dapat memberikan manfaat diantaranya:Sebagai bahan pertimbangan bagi guru matematika untuk merancang model atau strategi pembelajaran yang bertujuan untuk mengoptimalkan atau meningkatkan kreativitas siswa berdasar temperamen, dan dijadikan rujukan penelitian selanjutnya untuk penelitian tentang kreativitas siswa dalam menyelesaikan masalah matematika berdasarkan perbedaan temperamen.

\section{Kajian Pustaka}

Berpikir merupakan suatu kegiatan mental yang dialami seseorang bila mereka dihadapkan pada suatu masalah atau situasi yang harus diselesaikan.Proses berpikir terdiri dari tiga langkah, yaitu pembentukan pengertian, pembentukan pendapat, dan penarikan kesimpulan.

Jika ditinjau berdasar tingkatannya, maka berpikir kreatif menempati urutan tertinggi dalam berpikir (Soedjadi, 2007). Hal ini mencerminkan bahwa berpikir kreatif merupakan aktivitas mental yang melibatkan kemampuan kognitif individu paling komplek yang ada pada tahap berpikir. Menurut Pehnoken (1997), kreativitas tidak hanya terjadi pada bidang-bidang tertentu, seperti seni, sastra, atau sains, melainkan juga ditemukan dalam berbagai bidang kehidupan, termasuk matematika. Holland (Mann, 2005) mengidentifikasi aspek-aspek kemampuan berpikir kreatif matematis, yaitu kelancaran, keluwesan, keaslian, elaborasi, dan sensitivitas. Menurut Livne (2008), berpikir kreatif matematis merujuk pada kemampuan untuk menghasilkan 
solusi bervariasi yang bersifat baru terhadap masalah matematika yang bersifat terbuka.

Dalam pembelajaran matematika, suatu masalah dapat muncul saat guru memberikan sebuah soal, dan siswa tidak dengan segera bisa bertindak atau belum mampu secara langsung mengetahui cara-cara penyelesaian menggunakan pengetahuan matematika yang ia miliki.Terdapat dua macam masalah matematika, sebagaimana diungkapkan oleh Polya (1973) yaitu: (1). Masalah untuk menemukan dan (2) Masalah untuk membuktikan. Dari penelitian ini, masalah matematika yang digunakan adalah masalah untuk menemukan. Karena menurut peneliti, masalah untuk menemukan dapat digunakan untuk mengetahui profil kreativitas siswa dalam menyelesaikan masalah matematika daripada masalah membuktikan.Untuk mengetahui kemampuan berpikir kreatif seseorang ditunjukkan melalui hasil pemikiran atau kreativitasnya dalam menghasilkan sesuatu yang baru.Jadi seseorang dikatakan memiliki tingkat kemampuan berpikir kreatif tinggi jika dia mampu memberikan kemungkinan jawaban dan cara yang bernilai benar.Guilford (Jahja, 2004: 25) menemukan adanya lima sifat yang menjadi ciri kemampuan berpikir kreatif yaitu: a). Kelancaran, b). Keluwesan, c). Keaslian, d). Penguraian, e). Perumusan kembali.

Getzles dan Jackson (Silver, 1997) mengemukakan cara untuk mengukur kemampuan berpikir kreatif matematis, yakni dengan soal terbuka (open-ended problem).Menurut Simada (1997) permasalahan terbuka (open-ended) adalah suatu permasalahan yang mempunyai banyak penyelesaian atau banyak cara untuk mendapatkan penyelesaian. Masalah open-ended diyakini lebih mendorong kreativitas dan motivasi berpikir matematika siswa secara lebih bemakna dan bervariasi.

Penilaian kreativitas dalam penelitian ini menggunakan tiga karakteristik yaitu: (1). Kefasihan penyelesaian masalah meliputi kemampuan menyelesaikan masalah dan memberikan banyak jawaban terhadap masalah tersebut. (2). Fleksibilitas penyelesaian masalah meliputi kemampuan menggunakan beragam strategi untuk memperoleh jawaban terhadap masalah tersebut. (3). Orisinalitas penyelesaian masalah meliputi pada keaslian berpikir untuk 
menyelesaikan suatu masalah yang tidak sama dengan pemikiran orang pada umumnya.

Pengertian temperamen dan kepribadian sering terjadi kekacauan. Namun secara umum keduanya terdapat perbedaan. Temperamen dilihat sebagai disposisi yang sangat erat hubungannya dengan faktor-faktor biologis atau fisiologis dan karenanya sedikit sekali mengalami modifikasi di dalam perkembangan. Dari sini peranan keturunan lebih penting atau besar daripada segi-segi kepribadian yang lain. : temperamen adalah aspek kejiwaan daripada kepribadian, temperamen dipengaruhi oleh konstitusi jasmaniah, dan temperamen dibawa sejak lahir oleh sebab itu sukar dirubah oleh pengaruh dari luar. Hippocrates, seorang bapak ilmu pengobatan dari Yunani (460-370 SM), mengemukan suatu teori yang mengatakan bahwa pada dasarnya ada 4 (empat) tipe temperamen dasar yang dimiliki oleh manusia. Adanya keempat tipe temperamen ini adalah akibat dari 4 (empat) macam cairan tubuh yang sangat penting di dalam tubuh manusia; yaitu darah, empedu kuning, empedu hitam dan flegma.Hippocrates memberi nama temperamentemperamen tersebut sanguine, kolerik, melankolik, plegmatik (Arif, 2009).Sanguin (Sanguine). Sanguin adalah orang yang sangat bersemangat dalam hidupnya. la selalu tampak ceria, hangat, bersahabat, dan sangat menikmati hidup. Hal ini disebabkan karena ia memiliki sifat yang mudah menerima sehingga kesan-kesan dari luar dapat dengan mudah masuk ke dalam hatinya. Seorang sanguin cenderung lebih mendasarkan perasaannya daripada pemikirannya saat ia mengambil keputusan.Kolerik (Choleric) Kolerik memiliki kemauan keras dalam mencapai sesuatu. la adalah seorang yang aktif, praktis, cekatan, mandiri, dan sangat independen. la cenderung bersikap tegas dan berpendirian keras dalam mengambil keputusan bagi dirinya sendiri dan bagi orang lain. la adalah tipe orang yang sangat menyukai aktivitas.Melankoli (Melancholy). Dari empat temperamen yaitu sanguin, kolerik, plegmatik dan melankoli, melankoli merupakan temperamen yang paling kaya.Secara umum orang yang mempunyai temperamen melankoli ini bercirikan sebagai berikut: 1). Berpikir mendalam; 2). Berbakat; 3). Perfeksionis; 4). Serius dan tekun; 5). Pemurung; 6). Terlalu peka; 7). Menghindari kritik; 8). Analitis; 9). Perasa terhadap orang lain; 10). Idealis; 11). 
Artistik dan musikal; 12). Menghargai keindahan.Phlegmatik (Phlegmatic)

Phlegmatik memiliki sifat alamiah pendamai. la biasanya menghidari kekerasan. Secara umum orang yang bertemperamen phlegmatik mempunyai ciri- ciri sebagai berikut: 1). Mengamati yang lain; 2). Mudah dihibur; 3). Dapat diandalkan; 4). Mudah setuju; 5). Egois; 6). Suka menggoda; 7). Penakut; 8). Pemalas; 9). Diam-diam keras kepala; 10). Kepribadian rendah hati; 11). Simpatik dan baik hati; 12). Bahagia menerima kehidupan; 13). Serba guna.

Beberapa ciri orang kreatif adalah kemampuan untuk menghasilkan ide, gagasan, pemecahan, cara kerja, memiliki kemampuan berpikir segala arah untuk mencari jawaban yang berbeda dari umumnya (yang mungkin ada). Kepribadian kreatif menurut Guilford meliputi dimensi kognitif (yaitu bakat), dan dimensi non kognitif (yaitu minat, sikap dan kualitas temperamen). Ciri-ciri non kognitif sama pentingnya dengan ciri kognitif, karena tanpa ditunjang oleh kepribadian yang sesuai (dalam hal ini temperamen) maka kreativitas seseorang tidak dapat berkembang secara wajar. Kecakapan kreatif menentukan apakah individu dapat menampilkan perilaku kreatifnya tergantung dari ciri- ciri motivasi, sikap dan temperamennya.Kreativitas dapat pula ditinjau dari kondisi pribadi dan lingkungan yang mendorong individu ke perilaku yang kreatif.Penjelasan di atas juga didukung oleh Ernst Meumann (Suryabrata, 1982) dalam bukunya yang berjudul Intelligenz und Wille, menggambarkan watak sebagai disposisi kemauan yaitu

$$
\text { watak } \longrightarrow \text { kemauan } \longrightarrow \text { perbuatan }
$$

Di sini kemauan mengandung tiga aspek pokok yaitu (1). Aspek yang mempunyai dasar kejasmanian. (2). Aspek Afektif yang menjelma dalam temperamen.

\section{Metode Penelitian}

Penelitian ini bertujuan untuk mendeskripsikan profil kreativitas siswa Sekolah Menengah Pertama dalam menyelesaikan masalah matematika ditinjau dari perbedaan temperamen. Berdasarkan hal tersebut penelitian ini dikatagorikan penelitian deskriptif dengan pendekatan kualitatif. Subjek Penelitiandipilih 4siswa yaitu: 1 siswa dengan temperamen kolerik, 1 siswa dengan temperamen sanguin, 1 siswa dengan temperamen phlegmatik dan 1 
siswa dengan temperamen melankolik. Waktu pengisian angket temperamen selama 30 menit.Setelah semua temperamen terisi, maka kepada siswa terpilih diberikan tes penyelesaian masalah.Instrumen penelitian yang utama dalam penelitian kualitatif ini adalah peneliti sendiri. Hal yang didukung instrumen pendukung sebagai berikut:Angket Temperamenyang berisi 40 pertanyaan. Soal Tesyang mewakili materi geometri ruang yang sesuai dengan kurikulum SMP kelas VIII. Pedoman Wawancaradigunakan sebagai acuan dalam melaksanakan wawancara. Metode pengumpulan data dimulai dari penentuan subjek. Setelah subjek didapatkan, maka dilakukan wawancara terhadap setiap subjek.Setelah wawancara, triangulasi yang dilakukan dalam penelitian ini adalah triangulasi waktu. Untuk mendapatkan data yan valid, peneliti membandingkan hasil tes dan wawancara pertama dan kedua, jika hasilnya konsisten maka dikatakan valid dan akan dianalisis dengan cara reduksi data, penyajian data, dan penarikan kesimpulan.

\section{Hasil Penelitian dan Pembahasan}

1. Profil Kreativitas dalam Menyelesaikan Masalah Matematika Oleh Siswa dengan Temperamen Kolerik

Kreativitas dalam menyelesaian masalah matematika oleh siswa SMP dengan temperamen kolerikdari aspek kefasihannya subjek mampu menggambar 7 jawaban yang berbeda dan bernilai benar. Jawaban yang ia tuliskan bervariasi baik bentuk bangun maupun perhitungannya. Salah satunya mampu menggambar gabungan dua bangun ruang diantaranya bangun balok, bangun prisma segitiga, prisma trapesium. Dalam wawancara diketahui bahwa siswa dengan temperamen kolerik dapat memberikan penjelasan yang tepat mengenai cara membagi menjadi dua bangun beserta perhitungan yang ia tuliskan. Siswa dengan temperamen kolerik dalam aspek fleksibilitas memberikan cara yang berbeda untuk membagi kue tersebut selain menggunakan volume bangun ruang hasil dari pembagian kue tersebut, juga menggunakan kotak mainan yang dilubangi dengan ukuran yang sama dengan pembagian kue tersebut, mengadakan percobaan fisika dengan catatan bahwa jika bangun tersebut dimasukkan ke dalam gelas dan hasil ukurnya airnya menunjukan angka yang sama 
maka bangun itu akan sama, melihat sudut-sudut yang bersesuaian pada hasil kue yang telah dibagi. Jawaban yang diberikan sangat menarik dan berasal dari pikian siswa itu sendiri. Dari aspek orisinal, subjek menjelaskan munculnya ide dari kehidupan sehari-hari diataranya waktu ulang tahun pernah memotong kue, waktu melihat adiknya bermain kotak maianan dan memasukkannya, dan melihat ibunya pernah memotong kue secara zig zag.

2. Profil Kreativitas dalam Menyelesaikan Masalah Matematika Oleh Siswa dengan Temperamen Sanguin

Kreativitas dalam menyelesaikan masalah matematika oleh siswa SMP dengan temperamen sanguin dalam aspek kefasihan subjek membagi kue bolu menjadi dua bagian yang sama. Subjek mampu memberikan 6 jawaban yang berbeda diantaranya membagi ditengah-tengah panjang kue, memmbagi di tengah-tengah tinggi kue, membagi di tengah lebar kue. Ketiga jawaban itu diperoleh kue yang menyerupai balok. Sedangkan Yang ke-empat, ke-lima dan ke-enam subjek membagi miring dari pojok ke pojok sehingga diperoleh bangun prisma segitiga. Siswa dengan temperamen sanguin memahami materi dengan baik, tetapi dalam aspek fleksibilitas subjek hanya mampu menemukan satu cara yaitu dengan menggunakan rumus volume bangun ruang yang diperoleh dari masing-masing kue yang telah dibagi. Misalnya volume bangun ruang baok, prisma segitiga. Penyelesaian yang dibuatnya berasal dari pikian siswa itu sendiri. Subjek dalam aspek orisinal menjelaskan asal ide untuk menyelesaikan masalah tersebut diperoleh dari pengalaman sendiri diantaranya subjek terinspirasi waktu melihat ibunya memotong kue di tengah-tengah panjang kue, membagi kue astor dengan adiknya, memotong penghapus waktu di sekolah dikarenakan tidak membawa penghapus. Di samping itu subjek juga terinspirasi dari kejadaian di sekeliling rumah misalnya melihat pak tukang waktu memotong ubin menjadi bentuk segitiga, dan melihat atap rumah yang bentuknya menyerupai prisma segitiga.

3. Profil Kreativitas dalam Menyelesaikan Masalah Matematika Oleh Siswa SMP dengan Temperamen Phlegmatis.

Kreativitas dalam menyelesaikan masalah matematika oleh siswa SMP dengan temperamen phlegmatis dalam 
aspek kefasihan subjek mampu menuliskan lebih dari tiga jawaban tepatnya sebayak 5 jawaban. Diantaranya yang pertama subjek membagai panjang kue di tengah-tengah nya. Sehingga dari pembagian tersebut diperoleh menyerupai bangun balok. Yang ke-dua subjek membagi di tengah-tengah lebar kue sehingga diperoleh menyerupai balok. Yang ke-tiga subjek membagi di tegah-tengah tinggi kue tersebut sehingga diperoleh sama dengan jawaban sebelumnya menyerupai balok. yang ke-empat subjek membagi kue tersebut dengan cara menyilang membentuk bidang diagonal sehingga diperoleh menyerupai prisma segitiga. Dan yang terakhir subjek membagi kue tersebut dengan cara menyilang membentuk bidang diagonal dan diperoleh menyerupai prisma segitiga. Siswa ini dapat menjelaskan apa yang telah dikerjakannya secara umum, tetapi dalam aspek fleksibiltas siswa ini hanya menggunakan satu cara untuk membagi yang telah dibuatnya yaitu menggambar lalu menentukan ukurannya dan rumus volumenya untuk menghitung volumenya. Diantaranya menghitung volume hasil dari pembagian kue tersebut misalnya bangun balok dengan rumus volume $p \times l \times t$. Prisma segitiga mempunyai rumus volume $\frac{1}{2} \times a \times t \times$ $t_{\text {prisma. }}$ Siswa dengan temperamen ini menyelesaikan masalah matematika sesuai dengan apa yang telah diajarkan di sekolah. Subjek dalam aspek orisinal untuk menyelesaikan masalah membagi kue tersebut terinspirasi dari kegiatan yang dilakukan baik dari subjek sendiri ataupun dari orang-orang sekitar. Misalkan teringat oleh ibunya yang pernah memotong kue seperti itu, waktu membeli roti di toko roti, dan waktu ada tugas kelompok untuk membuat alat peraga prisma segitiga yang terbuat dari mika.

4. Profil Kreativitas dalam Menyelesaikan Masalah Matematika Oleh Siswa dengan Temperamen Melankolik

Kreativitas dalam menyelesaikan masalah matematika oleh siswa SMP dengan temperamen melankolik dalam aspek kefasihan subjek hanya mampu menuliskan 2 jawaban, itupun hanya yang standar saja misalkan subjek membagi di tengah- tengah panjang kue tersebut sehingga diperoleh menyerupai balok, dan yang kedua subjek membagi kue tersebut di tengah-tengah tinggi kue sehingga 
diperoleh menyerupai balok. Subjek dalam aspek fleksibilitas hanya menggunakan satu cara untuk membagi yang telah dibuatnya yaitu gambar lalu menentukan ukurannya dan rumus volumenya untuk menghitung volume masing-masing bangun. Siswa dengan temperamen melankolik tidak merespon suatu tugas dengan sangat teliti dan dalam aspek orisinal, subjek berangan-angan kalau kue tersebut menyerupai balok dan kadang- kadang subjek membagi kue tersebut dengan cara membagi di tengah-tengah panjang kue tersebut.

\section{Penutup}

1. Simpulan

Berdasarkan pembahasan hasil penelitian yang telah diuraikan, berikut adalah kesimpulannya:

1) Profil kreativitas siswa SMP dalam penyelesaian masalah matematika berdasarkan temperamen kolerik adalah sebagai berikut:

a) Kefasihan: siswa dengan temperamen kolerik memberikan jawaban membagi kue sebanyak 7 (tujuh) yang dimintakan dengan benar yaitu membagi kue tersebut dengan membagi lebar roti menjadi dua bagian, membagi panjangnya menjadi dua bagian, membaginya miring serong ke kanan dari roti tersebut sehingga berbentuk prisma segitiga, membagi roti miring serong ke kanandan potongannya berada di tengah sehingga diperoleh bentuk prisma trapesium, membagi kue tersebut dengan berkelok-kelok yang terdiri dari dua kelok, membagi roti dengan bentuk zig zag, dan yang terakhir dengan membagi lebar kue atau membagi kue dari samping.

b) Fleksibilitas: siswa dengan temperamen kolerik menemukan cara yang berbeda untuk mendapatkan jawaban sebanyak 4(empat) cara yaitu menggunakan rumus volume balok atau rumus volume prisma segitiga, melihat besar sudut yang bersesuaian, mendekatkan hasil dari pembagian kue tersebut sehingga akan ketemu bahwa ukuran dari sisi-sisinya akan sama, membuat kotak mainan kemudian dilubangi berbentuk seperti bangun tersebut dan memasukkan kedua bangun tersebut ke lubang mainan maka akan masuk dengan lancar, dengan membuat percobaan dengan 
menggunakan gelas yang berisi air kemudian dimasukkan hasil dari pembagian tadi ke dalam gelas yang berukuran dan melihat ukuran air sampai air tersebut berhenti naik.

c) Orisinalitas: siswa dengan temperamen kolerik memberikan penjelasan bagaimana munculnya ide untuk menyelesaikan masalah yang diberikan dikaitkan dengan kehidupan sebari-hari diantaranya memotong kue waktu ulang tahun, melihat adiknya bermain kotak maianan, melihat ibunya memotong kue secara zig zag.

2) Profil Kreativitas Siswa SMP dalam Penyelesaian Masalah Matematika berdasarkan temperamen sanguin adalah sebagai berikut:

a) Kefasihan : siswa dengan temperamen sanguin memberikan jawaban membagi kue sebanyak 6 (enam) yang dimintakan dengan benar yaitu membagi kue di tengah-tengah panjang kue, membagi kue tersebut dari samping atau membagi tinggi kue tersebut, membagi lebar kue, membagi kue tersebut miring sehingga diperoleh prisma segitiga, membagi kue tersebut sama dengan diperoleh prisma segitiga, membagi kue tersebut miring melalui diagonal dalamnya.

b) Fleksibilitas: siswa dengan temperamen sanguin tidak menemukan atau membuat cara berbeda, selain dengan cara menghitung volume balok dan volume prisma segitiga.

c) Orisinalitas: siswa dengan temperamen sanguin memberikan penjelasan tentang bagaimana asal ide itu muncul dikaitkan dengan kegiatan sehari-hari misalnya terinspirasi waktu ibunya memotong kue, waktu melihat temannya memotong penghapus saat di kelas, terinspirasi dari tukang yang renovasi rumah dengan memotong ubin dinding menjadi bentuk segitiga, bentuk atap rumah.

3) Profil Kreativitas Siswa SMP dalam Penyelesaian Masalah Matematika berdasarkan temperamen Phlegmatik adalah sebagai berikut:

a) Kefasihan: siswa dengan temperamen phlegmatik memberikan jawaban membagi kue sebanyak 5 (lima) yang dimintakan dengan benar yaitu membagi tinggi kue tersebut, membagi lebar kue tersebut, membagi kue tersebut menurut diagonalnya miring,membagi panjang kue tersebut, membagi diagonal dalam dari kue tersebut. 
b) Fleksibilitas: siswa dengan temperamen phlegmatik tidak menemukan atau membuat cara berbeda, hanya dengan menghitung volume bangun dari hasil pembagian kue tersebut diantaranya menggunakan rumus volume bangun balok, rumus volume prisma segitiga.

c) Orisinalitas: siswa dengan temperamen phlegmatik memberikan penjelasan tentang asal ide itu muncul dalam menyelesaikan masalah dikaitkan dengan masalah yang terjadi di lingkungan sekitar diantaranya siswa teringat waktu ibunya memotong kue, siswa pada waktu membeli kue dengan potongan menyerupai bentuk prisma segitigadi toko kue, siswa mengalami sendiri waktu praktek membuat alat peraga prisma segitiga di sekolah.

4) Profil Kreativitas Siswa dalam Penyelesaian Masalah Matematika berdasarkan temperamen Melankolik adalah sebagai berikut:

a) Kefasihan : siswa dengan temperamen memberikan jawaban membagi kue tesebut sebanyak 2 (dua) yang dimintakan dengan benar yaitu siswa membagi kue tersebut di tengah-tengah panjang kue, membagi kue tersebut pada bagian tengah-tengah tinggi kue tersebut.

b) Fleksibilitas: siswa dengan temperamen melankolik menemukan atau membuat cara berbeda, hanya dengan menghitung volume dari hasil pembagian kue tersebut yaitu menggunakan rumus volume balok.

c) Orisinalitas: siswa dengan temperamen melankolik dalam menyelesaikan masalah yang diberikan belum memberikan penjelasan tentang bagaimana munculnya ide untuk menyelesaikan masalah.

2. Saran

Dari hasil penelitian ini, beberapa saran yang dapat penulis kemukakan antara lain: (1). Diperlukan penelitian lebih lanjut untuk lebih memantapkan hasil dari penelitian dalam mengamati kreativitas penyelesaian masalah matematika berdasarkan temperamen. (2). Penelitian inidapatdipakaiolehpendidiksebagaibahanpertimbangandala mmerancang model pembelajaran yang dapatmeningkatkankreativitassiswadalampemecahanmasala hmatematikaberdasarkantemperamen yang dimiliki siswa. 


\section{Daftar Pustaka}

Hudojo, Herman. 2001. Pengembangan Kurikulum Matematika dan Pembelajaran Matematika. Malang: Universitas Negeri Malang.

Jahja, Yudrik. 2004. Wawasan Pendidikan. Jakarta: Depdiknas.

Khodijah, Nyayu. 2006. Psikologi Belajar. Palembang.: IAIN Raden Fatah Press tersedia dari http://www. Andradogi.com (diakses tanggal 2 Mei 2011).

Littauer, Florence. 2011. Personality Plus. Jakarta: Binarupa Aksara.

Maryanto, Yoga. 2008. Kemampuan Berpikir IImu Lingkungan Tingkat Tinggi Mahasiswa UMMI Sukabumi. Proposal. UMMI. Sukabumi.

Munandar, Utami. 1999. Mengembangkan Kreativitas Anak Berbakat. Jakarta: Rineka Cipta.

Murniati, Endyah. 2012. Pendidikan \& Bimbingan Anak Kreatif. Yogyakarta: Pustaka Insan Madani.

Novyanto, okasatria. 2008. Empat Jenis Temperamen Manusia. [on line].

Tersedia:http://okasatria.blogspot.com/2008/02/empatjenis-temperamen-manusia.html.(diakses tanggal 5 Mei 2011).

Ormrod, Ellis Jeanne, 2008. Educational Psycology Developing Learners. University of Northen Colorado (Emerita).

Pehnoken, E. 1997. The State-of-Art in Mathematical Creativity. Zentralblatt für Didaktik der Mathematik (ZDM)-The International Journal on Mathematics Education.

Tersedia:http://www.emis.de/journals/ZDM/zdm

973a1.pdf. (Diakses tanggal 14 Oktober 2011).

Siagian, Yeni D.S. 2003. Si Melankolis Cenderung Bunuh Diri. [On line]. Tersedia: http://kompas.com/kesehatan/newa/0306/18/113314.ht ml.(Diakses tanggal 5 Mei 2011).

Silver, E. A. 1997. Fostering Creativity through Instruction Rich in Mathematical Problem Solving and Problem Posing. Zentralblatt für Didaktik der Mathematik (ZDM) - The International Journal on Mathematics Education. [Online]. Tersedia di: http://www.emis.de 
/journals/ZDM/zdm973a3.pdf. ISSN 1615-679X. (Diakses tanggal 14 Oktober 2011).

Siswono, Tatag. Y.E. 2007. Penjenjangan Kemampuan Berpikir Kreatif dan Identifikasi Tahap Berpikir Kreatif Siswa dalam Memecahkan dan Mengajukan Masalah Matematika. Surabaya: Pps. UNESA. Disertasi.

Siswono, Tatag. Y. E. 2008. Mengajar dan Meneliti. Surabaya: Unesa University Press.

Skemp, R. R. 1971. The psychology of learning mathematics. New York: Penguin Books LtdPolya, G. (1973). How to solve it. A new aspect of mathematical method. New Jersey: Princeton University Press.

Sudaryanto. 2000. Clinical reasoning dan Berpikir Kritis. [on line].

Tersedia

http://www.fk.undip.ac.id/pengembangan-

pendidikan/78-clinical-reasoning-dan-berpikir-

kritis.html.(diakses tanggal 5 Mei 2011).

Sudiarta, Putu. 2012.Pengembangan Kompetensi Berpikir Divergen dan Kritis Melalui Pemecahan Masalah Matematika Open Ended. (on line) (diakses tanggal 22 januari 2012).

Suryabrata, Sumadi. 1982. Psikologi Kepribadian. Jakarta: CV. Rajawali.

Sutanto, M. Edi. (2003). Hubungan Antara Temperamen Karyawan, Pemberian Kompensasi, Dan Jenjang Karier Yang Tersedia Terhadap Prestasi Kerja Karyawan.(on line) Tersedia http://adedepokz.blogspot.com/http:www.petra.ac.id p uslit/files/publish.ed/jornals/MAN/MAN030501/MAN030 50104.pdf. (Diakses tanggal 5 Mei 2011).

Wahidin, Didin. 2009. Berpikir Kreatif. [on line]. Tersedia:http://didinuninus.blogspot.com/2009/03/berfikir kreatif.html. (Diakses tanggal 20 April 2011).

Worthington, M. (2006). Creativity Meets Mathematics. [Online] Tersedia: http://www.children mathematics.net/creativity_meets_mathematics.pdf.

(Diakses 14 Januari 2011). 